\title{
Exploring the carry on benefits of acquired Problem- based learning skills into the clinical phase; Listening to the opinions of the prime beneficiaries after the transition
}

\author{
Altaf Bandy ( $\sim$ ahbandy@ju.edu.sa ) \\ College of Medicine, Jouf University Sakaka, AI Jouf SAUDI ARABIA
}

Research article

Keywords: Collaborative learning; Hybrid Problem based learning strategy; cognitive skills; self-directed learning; problem solving skills.

Posted Date: July 11th, 2019

DOl: https://doi.org/10.21203/rs.2.11235/v1

License: (9) (1) This work is licensed under a Creative Commons Attribution 4.0 International License.

Read Full License 


\section{Abstract}

Background The benefits of student acquired Problem-based learning (PBL) skills in the preclinical phase might carry-on into the clinical phase and the application of these skills in the understanding of clinical subjects remains uncertain. Current study is aimed at exploring the perceptions of carry-on benefits of problem-based learning skills into the clinical phase. Methods Using a pre-validated questionnaire, the benefits of PBL skills in the clinical phase were evaluated by seven questions on a five-point Likert scale. A non- parametric test assessed variation between the groups. $p$-value of $<0.05$ was considered statistically significant for this study. Results The overall mean score of the perception of acquired preclinical benefits of PBL in clinical phase was $4.57 \pm 2.41$; females demonstrating higher mean scores

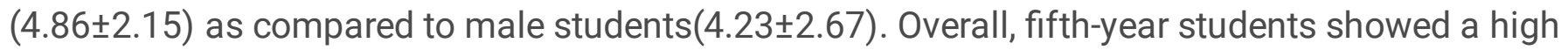
satisfaction(4.84 \pm 2.36$)$ of the effective use of preclinical PBL skills in clinical courses. 5th-year female student's perception of preclinical collaborative learning skill benefits in clinical courses was significantly $(p<0.03)$ higher than male. Conclusions The study concludes that a substantial preclinical PBL educational strategy benefits are carried into the clinical phase especially the long-lasting self-direct learning, collaborative learning and problem-solving skills consistent with demanding abilities of a competent physician.

\section{Background}

The teaching strategy in medical education has shifted to an innovative strategy that is student-centered, activity-based, commonly referred to as problem-based learning (PBL) $[1,2]$. PBL primarily designed for the preclinical phase of the medical curriculum, empower students to self-direct their learning and independence in controlling their studies [3]. The reported advantages of PBL include better knowledge retention, collaborative learning, enhanced problem-solving skills and greater integration of preclinical and clinical studies [4-6]. Globally medical institutions have implemented PBL as a sole instructional strategy or as a hybrid PBL strategy in their undergraduate curriculum [7-9].

The College of Medicine at Jouf University of Saudi Arabia has implemented an integrated hybrid PBL system from the first year of its inception. The hybrid model of problem-based learning comprises of a problem constructed on a weekly theme, supported by traditional lectures, clinical skills and labs covering the same theme. In Jouf faculty of medicine undergraduate curriculum, PBL forms an integral part of the preclinical phase. The first session of PBL is held on the first day of the week and lasts for two hours followed by another session on the last day of the week. A tutor facilitates these sessions. In the first session, students discuss a problem in small groups exploring the reasons for the condition and identify problem-related gaps in knowledge. The students' self-direct learning of the identified gaps during dedicated slots in the timetables. The second session is held on the last day of the week where the students discuss the acquired knowledge among themselves to solve the problem. In between these two sessions, traditional lectures, clinical skills, and labs on the same week theme support students to fulfil their knowledge gap about the PBL theme. In the clinical phase, the $4^{\text {th }}$ and $5^{\text {th }}$-year students are exposed to real-world bedside teaching facilitated by a tutor. Clinical teaching is also supported by traditional 
lectures. Many reports have evaluated the benefits of PBL, as an instructional method in professional education mainly focusing on the basic year medical students [10-12]. Reports on the appropriateness and effectiveness of PBL as an instructional method in the medical curriculum are encouraging in this part of the world [13-15].

Currently, health services have become more service oriented with less importance to clinical teaching forcing a change in clinical phase teaching of undergraduate students. Akin to PBL, medical colleges around the globe have started a case-based curriculum in the clinical phase consistent with education change theory of self-directed gain in knowledge [16]. Having an effective PBL instructional strategy in the preclinical phase will carry on its benefits into the clinical phase encouraging students' self-directed and collaborative learning in the foreseeable fluid situation of the change in priorities. These benefits of PBL initiate higher group functioning and enhance achievement [17]. Till to date, in literature, none of the study focused on the preclinical phase acquired knowledge carry on benefits into the clinical phase learning outcomes and its effectiveness in patient care practice.

In light of the above background, the current study was carried out with an objective to gather the student opinions about the possible carryon benefits of PBL skills into the clinical phase of the medical curriculum at the college of medicine.

\section{Methods}

\section{Participants and study design}

This cross-sectional study was conducted in the college of medicine at Jouf University, Sakaka Aljouf, Saudi Arabia. The Study targeted both male and female students from the Clinical phase (fourth and fifth year). Clinical phase primarily focuses on bedside teaching in a hospital supported by traditional lectures. We included the clinical phase students because they are the primary end users of preclinical PBL system. The participation of students in this study was voluntary. The data was collected between March2019 to May-2019 with the aid of a well-structured Google form-based questionnaire, link of which was shared with the students. The questionnaires that were responded in totality were included in the final analysis. All students of clinical phase were targeted. Using a guesstimate of $50 \%$ participants perceive PBL strategy as beneficial in the understanding of clinical subjects, an online raosoft sample size calculator was used to arrive at the minimum number of participants required for this study. At a $95 \%$ confidence level and $5 \%$ margin of error, ninety-eight students were required for this study. The questionnaire used for the assessment of perceptions of benefits of PBL has been validated and used in the earlier study by Abdulmajeed A. Al-Drees and his colleagues [14]. Seven questions assessed the benefits of PBL. The five-point Likert scale was used to answer the questions. The local bioethical committee of Jouf University approved the study protocol vide no: 2-16-4/40.

\section{Statistical analysis}


The data collected was coded before entry. Statistical Package for Social Sciences (SPSS)version20 (IBM Corporation, Armonk, NY USA) was used for data analysis. The Likert Scale responses were merged as "agree" (Agree and strongly agree) "neutral "and "disagree" (Disagree and strongly disagree) for categorization and for further use of statistical tests of significance. Chi-Square test was used to measure variation between the fourth and fifth year and between males and females. The variation was considered significant at a $\mathrm{p}$-value of $<0.05$.

\section{Results}

With a response rate of $95 \%$, the completely answered questionnaire was received from 94 students. Of these $43(45.7 \%)$ were males and $51(54.3 \%)$ were females, same proportion comprised $4^{\text {th }}$ and $5^{\text {th }}$-year medical students. Table-1 presents the students' perception of preclinical acquired PBL benefits into the clinical phase. The overall mean score of the perception regarding PBL benefits in clinical phase was $4.57 \pm 2.41$, wherein, female students demonstrated a higher mean score $(4.86 \pm 2.15)$ as compared to male students (4.23 \pm 2.67$)$. Moreover, fifth-year students mean score $(4.84 \pm 2.36)$ revealed higher satisfaction with preclinical PBL skills as compared to $4^{\text {th }}$ year students $(4.24 \pm 2.46)$. The results show an overall female student's perception of preclinical collaborative learning skill benefits in clinical courses significantly $(p<0.03)$ higher than male students. On the other hand, the benefits of collaborative learning skills in the clinical contexts were significantly $(p<0.03)$ higher among $5^{\text {th }}$ year students. PBL skill of identifying strengths and weaknesses was ranked significantly $(p<0.01)$ higher by female students.

Year-wise comparative analysis on the perception of carry- on PBL skills into the clinical years reveals that $5^{\text {th }}$ year students were benefited more $(4.8 \pm 1.82)$ from preclinical PBL educational system (Table-2). Similarly, gender comparison exhibits higher $(4.89 \pm 2.42)$ acquired PBL skill benefits among females in clinical phase (Table-3).

Figure 1 shows that, the $5^{\text {th }}$ year male students' retention of a high proportion of PBL skill of long-lasting self-directed learning $(69.6 \%)$, significant $(p<0.04)$ collaborative learning skills and knowledge acquisition abilities (73.9\%). Furthermore, $75 \%$ of $5^{\text {th }}$-year female students perceived the persistent benefits of identifying the weaknesses and strengths skill from the preclinical phase among the same gender from both years (Figure-1).

\section{Discussion}

The current study examines the clinical year student's perception regarding their prior acquired knowledge and skills and its effectiveness in the clinical phase. Earlier studies considered the acquisition of relevant knowledge, skills, and behaviors' as the prime educational objectives in PBL based medical curriculum rather than factual learning and use of these skills in a clinical context in the preclinical phase $[18,19]$. These educational objectives drive the student's critical thinking, initiate new ideas, gain skills, and knowledge and attitudes to become competent physician [20,21]. 
In the present study, more than $60 \%$ of students showed positive perception with their preclinical phase PBL strategy objectives carry on benefits in their current clinical phase courses. This in agreement with earlier study reports from Saudi medical schools conducted on preclinical students, that have revealed PBL as the most satisfactory, innovative and acceptable educational instructional approach in undergraduate medical curriculum $[13,15,22-26]$.

In addition to the student positive satisfaction towards PBL as an acceptable teaching method in medical curriculum, literature have explored other facets of PBL on enhancing the impact on students' cognitive abilities such as the previous knowledge retention, communication skills, everlasting self-directed learning skills, problem solving skill and individual analyzing skills [1, 13, 27-29]. PBL stimulate the learning of basic science contents as well as the impact on knowledge acquisition and application in preclinical concepts $[14,22]$. In contrast, some authors debated PBL impacts only the application of knowledge rather than knowledge acquisition [30]. However, literature is not available on the student perception on the effective application of their PBL based preclinical basic science knowledge in the clinical context. Application of acquired basic science knowledge in clinical phase courses is the potential outcome of any form of PBL in the medical curriculum. In our study, the 5th year students showed more positive perception pertaining to their gained basic science knowledge and its application in current courses as compared to 4th year students. This could be due to their longtime exposure to different clinical case analytics after preclinical phase that might have enhanced their basic science knowledge integration with clinical cases.

Interactions and collaboration within the small group enhance students' better understanding of the subject context in the preclinical phase [31]. Similarly, collaborative learning concept in PBL enhances the student performance in the differential diagnosis in the clinical phase by discussing the clinical case with others by applying the preclinical phase collaborative learning PBL skill. The students' perception in our study revealed their prior collaborative skills in preclinical PBL education, showed a positive impact in various clinical settings to improve their case-oriented knowledge.

Numerous studies reported that the PBL was improving interaction skills, teamwork, interpersonal skills, and independent decision making skill in small-group tutorials in the preclinical phase of undergraduate PBL integrated medical educational system [14, 32, 33]. In agreement, the present study, clinical year students' perception revealed PBL encourages them in developing curiosity, reasoning skills, and sole decision-making skills. This character is significant for efficient patient care in daily practice [34]. Aspegren et al reported that female students showed more cooperative, interpersonal skills and communication skills during PBL tutorials as compared to male students in the preclinical phase [35]. Interestingly, in our study female students perception towards the PBL stimulated decision-making skills carry on benefit in clinical phase was highly satisfactory as compared to male students.

Obviously, PBL enhances to develop different kinds of case diagnosing soft skills needed for their future clinical practice. Existing literature explored, PBL could enhance soft skills particularly, on students' motivation, independent problem solving with critical thinking and communication skills [36, 37]. Hmelo- 
Silver et al stated that appropriate designed relevant problems show a significant impact on the development of student problem reasoning strategies in addition to their previous knowledge [4]. In contrast, Berkson et al reported that PBL has no impact on problem-solving skills and knowledge acquisition [38]. Our study results show 5th year students strongly satisfied with problem-solving skills learned from their preclinical PBL system as compared to 4th year students. The differences in the level of satisfaction between these two groups might be due to their difference in experiences with various clinical cases during the clinical phase. Furthermore, earlier studies reported, PBL graduates are significantly high in problem-solving skills and interpersonal abilities and autonomous work management as compared to non-PBL graduates [14, 18, 39-42]. In addition, few studies reported that PBL was superior than traditional teaching methods in terms of better clinical performance rather than their factual and clinical knowledge $[43,44]$. A comparison study reported that students' from PBL medical curriculum showed more positive performances in clinical practice, whereas, non-PBL students were better in consultation skills [30].

PBL method enhances the student to take up an inquisitive style of learning and driven towards selfdirected learning [30]. Tsou et al. stated that students from PBL based educational system was more active in learning and had better learning skills and confidence in self-directed learning as compared with students from the lecture-based curriculum [42]. In this study, students' perception concerning PBL stimulus of self-directed learning carry on benefits in clinical phase noted as positive satisfaction among both years of the clinical phase.

However, almost all of the fifth-year students showed more positive satisfaction than $4^{\text {th }}$ years for the majority of the investigated items. The possible explanation for that could be the $5^{\text {th }}$ year students experience with numerous clinical cases and more chances to apply their preclinical acquired basic science knowledge and problem-solving skills during the clinical phase as compared to fourth year students as beginners in the clinical phase. However, the results of the study should be interpreted with caution as this question of the persistence of benefits has not been answered as per the available literature, hence no studies were available for comparing the results.

\section{Conclusions}

Our study concludes the persistence and carry on the benefits of acquired PBL skills from the preclinical phase into the clinical phase. The study emphasizes the students perceive a substantial persistence of the acquired PBL skills into the clinical phase indicating an effective PBL strategy implementation in the preclinical phase should we expect long-term benefits among primary end users of this strategy. On the other hand, strengthening preclinical PBL skills will improve the prospects of student academic and professional carrier. As a part of continuing reforms in the medical curriculum in Saudi Arabia, we advocate evaluation of acquired PBL skills that will help the administration to identify any dysfunctional implementation of hybrid PBL strategy in medical schools.

\section{Abbreviations}


PBL : Problem-based learning

SPSS: Statistical Package for Social Sciences

\section{Declarations}

\section{Ethics approval and consent to participate}

Ethics approval was obtained from the local bioethical committee of Jouf University vide no: 2-16-4/40. A written consent to participate was obtained.

\section{Consent to publish}

Not applicable

\section{Availability of data and materials}

The datasets used and/or analyzed during the current study are available from the corresponding author on reasonable request.

\section{Competing interests}

The author(s) declare(s) that they have no competing interests

\section{Funding}

This research did not receive any specific grant from funding agencies in the public, commercial, or notfor-profit sector

\section{Authors' contributions}

$A B$ designed the study, collected the data, analyzed and interpreted the data, and manuscript prepared.

\section{Acknowledgment}

The author thanks Shaik Rahiman for his support in manuscript formatting.

\section{Authors' Information}

Family and Community Medicine, College of Medicine, Jouf University, Sakaka, Kingdom of Saudi Arabia.

\section{References}

1. Dolmans DH, De Grave W, Wolfhagen IH, Van Der Vleuten CP: Problem-based learning: Future challenges for educational practice and research. Medical education. 2005; 39:732-741. 
2. Fisher M, Moore S: Enquiry-based learning links psychology theory to practice. British Journal of Midwifery. 2005; 13:148-152.

3. Baerveldt C: Constructivism contested: Implications of a genetic perspective in psychology. Integrative Psychological and Behavioral Science. 2013; 47:156-166.

4. Hmelo-Silver CE: Problem-based learning: What and how do students learn? Educational psychology review. 2004; 16:235-266.

5. Wood DF: Problem based learning. Bmj. 2003; 326:328-330.

6. Yaqinuddin A: Problem-based learning as an instructional method. J Coll Physicians Surg Pak. 2013; 23:83-85.

7. Azer SA: What makes a great lecture? Use of lectures in a hybrid PBL curriculum. The Kaohsiung journal of medical sciences. 2009; 25:109-115.

8. Lee Y-M, Mann KV, Frank BW: What drives students' self-directed learning in a hybrid PBL curriculum. Advances in Health Sciences Education. 2010; 15:425-437.

9. Telang A: Problem-based learning in health professions education: an overview. Archives of Medicine and Health Sciences. 2014; 2:243.

10. Nandi P, Chan J, Chan C, Chan P, Chan L: Undergraduate medical education: comparison of problembased learning and conventional teaching. Hong Kong Medical Journal. 2000; 6:301-306.

11. Preeti B, Ashish A, Shriram G: Problem based learning (PBL)-an effective approach to improve learning outcomes in medical teaching. Journal of clinical and diagnostic research: JCDR. 2013; 7:2896.

12. Schmidt HG, Vermeulen L, Van Der Molen HT: Longterm effects of problem-based learning: a comparison of competencies acquired by graduates of a problem-based and a conventional medical school. Medical education. 2006; 40:562-567.

13. Al-Damegh SA, Baig LA: Comparison of an integrated problem-based learning curriculum with the traditional discipline-based curriculum in KSA. Journal-College Of Physicians And Surgeons of Pakistan. 2005; 15:605.

14. Al-Drees AA, Khalil MS, Irshad M, Abdulghani HM: Students' perception towards the problem based learning tutorial session in a system-based hybrid curriculum. Saudi medical journal. 2015; 36:341.

15. Shamsan B, Syed A: Evaluation of problem based learning course at college of medicine, Qassim University, Saudi Arabia. International journal of health sciences. 2009; 3:249.

16. Aljarallah $B$, Hassan MS: Problem based learning ( $P B L$ ) vs. case based curriculum in clinical clerkship, internal medicine innovated curriculum, student prospective. International journal of health sciences. 2015; 9:147.

17. Van Berkel HJ, Dolmans DH: The influence of tutoring competencies on problems, group functioning and student achievement in problem-based learning. Medical Education. 2006; 40:730-736.

18. Beachey WD: A comparison of problem-based learning and traditional curricula in baccalaureate respiratory therapy education. Respiratory care. 2007; 52:1497-1506. 
19. Gerzina TM, Worthington R, Byrne S, McMahon C: Student use and perceptions of different learning aids in a problem-based learning (PBL) dentistry course. Journal of Dental Education. 2003; 67:641653.

20. Choi E, Lindquist R, Song Y: Effects of problem-based learning vs. traditional lecture on Korean nursing students' critical thinking, problem-solving, and self-directed learning. Nurse education today. $2014 ; 34: 52-56$.

21. Zahid MA, Varghese R, Mohammed AM, Ayed AK: Comparison of the problem based learning-driven with the traditional didactic-lecture-based curricula. International journal of medical education. 2016; 7:181.

22. AlHaqwi Al, Mohamed TA, Al Kabba AF, Alotaibi SS, Al Shehri AM, Abdulghani HM, Badri M: Problembased learning in undergraduate medical education in Saudi Arabia: Time has come to reflect on the experience. Medical teacher. 2015; 37:S61-S66.

23. Habib F, Baig L, Mansuri FA: Opinion of medical students regarding problem based learning. JPMA The Journal of the Pakistan Medical Association. 2006; 56:430.

24. Hagi SK, Al-Shawwa LA: Evaluation of second and fourth year undergraduate medical students' perception and acceptance of the problem-based learning process. Saudi medical journal. 2011; 32:1060-1065.

25. Joseph N, Sharada R, Animesh J, Nelliyanil M, Kotian SM, Rai S, Jain A: Perception towards problem based learning among medical students of a private medical college in South India. Br J Med Med Res. 2015; 9:1-10.

26. Lian J, He F: Improved performance of students instructed in a hybrid PBL format. Biochemistry and Molecular Biology Education. 2013; 41:5-10.

27. Dochy F, Segers M, Van den Bossche P, Gijbels D: Effects of problem-based learning: A metaanalysis. Learning and instruction. 2003; 13:533-568.

28. Wun Y, Tse EY, Lam T, Lam CL: PBL curriculum improves medical students' participation in smallgroup tutorials. Medical teacher. 2007; 29:e198-e203.

29. Yew EH, Schmidt HG: Evidence for constructive, self-regulatory, and collaborative processes in problem-based learning. Advances in Health Sciences Education. 2009; 14:251-273.

30. Hartling L, Spooner C, Tjosvold L, Oswald A: Problem-based learning in pre-clinical medical education: 22 years of outcome research. Medical teacher. 2010; 32:28-35.

31. Shankar PR, Nandy A: Student feedback on problem-based learning processes. The Australasian medical journal. 2014; 7:522.

32. Klegeris A, Hurren $\mathrm{H}$ : Impact of problem-based learning in a large classroom setting: student perception and problem-solving skills. Advances in physiology education. 2011; 35:408-415.

33. Ommar N: Perception of first and second year medical students on problem-based learning in Universiti Malaysia Sarawak. World App/ Sci J. 2011; 14:1628-1634. 
34. Nanda B, Manjunatha S: Indian medical students' perspectives on problem-based learning experiences in the undergraduate curriculum: One size does not fit all. Journal of educational evaluation for health professions. 2013; 10.

35. Aspegren K: BEME Guide No. 2: Teaching and learning communication skills in medicine-a review with quality grading of articles. Medical teacher. 1999; 21:563-570.

36. Hmelo-Silver CE, Barrows HS: Goals and strategies of a problem-based learning facilitator. Interdisciplinary journal of problem-based learning. 2006; 1:4.

37. Ibrahim NK, Banjar S, Al-Ghamdi A, Al-Darmasi M, Khoja A, Turkistani J, Arif R, Al-Sebyani A, Musawa A, Basfar W: Medical students preference of problem-based learning or traditional lectures in King Abdulaziz University, Jeddah, Saudi Arabia. Annals of Saudi medicine. 2014; 34:128-133.

38. Berkson L: Problem-based learning: have the expectations been met? Academic medicine. 1993.

39. Al-Shaikh G, Al Mussaed EM, Altamimi TN, Elmorshedy H, Syed S, Habib F: Perception of medical students regarding problem based learning. Kuwait Med J. 2015; 47:133-138.

40. Emerald NM, Aung PP, Han TZ, Yee KT, Myint MH, Soe T, Oo S: Students' perception of problem based learning conducted in phase1 medical program, UCSI University, Malaysia. South East Asian Journal of Medical Education. 2013; 7:45-48.

41. Hung W, Jonassen DH, Liu R: Problem-based learning. Handbook of research on educational communications and technology. 2008; 3:485-506.

42. Tsou K-I, Cho S-L, Lin C-S, Sy LB, Yang L-K, Chou T-Y, Chiang H-S: Short-term outcomes of a near-full PBL curriculum in a new Taiwan medical school. The Kaohsiung journal of medical sciences. 2009; 25:282-293.

43. Albanese MA, Mitchell S: Problem-based learning: A review of literature on its outcomes and implementation issues. ACADEMIC MEDICINE-PHILADELPHIA- 1993; 68:52-52.

44. Vernon DT, Blake RL: Does problem-based learning work? A meta-analysis of evaluative research. Academic medicine. 1993.

\section{Tables}

Table-1: Clinical phase student's perception regarding preclinical PBL benefits 


\begin{tabular}{|c|c|c|c|c|c|c|c|c|}
\hline Questions & Categories & $\begin{array}{l}\text { Total } \\
\text { Participants } \\
\text { n }(\%)\end{array}$ & $\begin{array}{l}\text { Male } \\
\text { n (\%) }\end{array}$ & $\begin{array}{l}\text { Female } \\
\text { n (\%) }\end{array}$ & $\begin{array}{l}P \text { - } \\
\text { value }\end{array}$ & $4^{\text {th }}$ year & $5^{\text {th }}$ year & $\begin{array}{l}P \text { - } \\
\text { value }\end{array}$ \\
\hline \multirow{3}{*}{$\begin{array}{l}\text { PBL helps me to } \\
\text { understand basic } \\
\text { sciences }\end{array}$} & Agree & $62(66)$ & $\begin{array}{l}27 \\
(62.8)\end{array}$ & $35(68.6)$ & \multirow[t]{3}{*}{0.46} & $26(60.5)$ & $36(70.6)$ & \multirow[t]{3}{*}{0.43} \\
\hline & Neutral & $19(20.2)$ & $8(18.6)$ & $11(21.6)$ & & $9(20.9)$ & $10(19.6)$ & \\
\hline & Disagree & $13(13.8)$ & $8(18.6)$ & $5(9.8)$ & & $8(18.6)$ & $5(9.8)$ & \\
\hline \multirow{3}{*}{$\begin{array}{l}\text { PBL helps me to } \\
\text { increase my basic } \\
\text { sciences knowledge }\end{array}$} & Agree & $67(71.3)$ & $29(67.4)$ & $38(74.5)$ & \multirow[t]{3}{*}{0.46} & $31(72.1)$ & $36(70.6)$ & \multirow[t]{3}{*}{0.22} \\
\hline & Neutral & $14(14.9)$ & $6(14.0)$ & $8(15.7)$ & & $4(9.3)$ & $10(19.6)$ & \\
\hline & Disagree & $13(13.8)$ & $8(18.6)$ & $5(9.8)$ & & $8(18.6)$ & $5(9.8)$ & \\
\hline \multirow{3}{*}{$\begin{array}{l}\text { PBL encourages self- } \\
\text { directed learning }\end{array}$} & Agree & $59(62.8)$ & $24(55.8)$ & $35(68.6)$ & \multirow[t]{3}{*}{0.43} & $24(55.8)$ & $35(68.6)$ & \multirow[t]{3}{*}{0.29} \\
\hline & Neutral & $16(17.0)$ & $9(20.9)$ & $7(13.7)$ & & $10(23.3)$ & $6(11.8)$ & \\
\hline & Disagree & $19(20.2)$ & $10(23.3)$ & $9(17.6)$ & & $9(20.9)$ & $10(19.6)$ & \\
\hline \multirow{3}{*}{$\begin{array}{l}\text { PBL method helps me } \\
\text { improve my decisions } \\
\text { making skills }\end{array}$} & Agree & $61(64.9)$ & $22(51.2)$ & $39(76.5)$ & \multirow[t]{3}{*}{0.03} & $28(67.4)$ & $32(62.7)$ & \multirow[t]{3}{*}{0.65} \\
\hline & Neutral & $12(12.8)$ & $7(16.3)$ & $5(9.8)$ & & $4(9.3)$ & $8(15.7)$ & \\
\hline & Disagree & $21(22.3)$ & $14(32.6)$ & $7(13.7)$ & & $10(23.3)$ & $11(21.6)$ & \\
\hline \multirow{3}{*}{$\begin{array}{l}\text { PBL method helps me } \\
\text { to develop problem- } \\
\text { solving skills }\end{array}$} & Agree & $63(67.0)$ & $29(67.4)$ & $34(66.6)$ & \multirow[t]{3}{*}{0.43} & $27(62.8)$ & $36(70.6)$ & \multirow[t]{3}{*}{0.32} \\
\hline & Neutral & $15(16.0)$ & $5(11.6)$ & $10(19.6)$ & & $6(14.0)$ & $9(17.6)$ & \\
\hline & Disagree & $16(17.0)$ & $9(20.9)$ & $7(13.7)$ & & $10(23.3)$ & $6(11.8)$ & \\
\hline \multirow{3}{*}{$\begin{array}{l}\text { PBL method } \\
\text { encourages } \\
\text { collaborative learning }\end{array}$} & Agree & $57(60.6)$ & $25(58.1)$ & $32(62.7)$ & \multirow[t]{3}{*}{0.03} & $20(46.5)$ & $37(72.5)$ & \multirow[t]{3}{*}{0.03} \\
\hline & Neutral & $24(25.5)$ & $8(18.6)$ & $16(31.4)$ & & $15(34.9)$ & $9(17.6)$ & \\
\hline & Disagree & $13(13.8)$ & $10(23.3)$ & $3(5.9)$ & & $8(18.6)$ & $5(9.8)$ & \\
\hline \multirow{3}{*}{$\begin{array}{l}\text { PBL method helps me } \\
\text { to identify my } \\
\text { strengths and } \\
\text { weaknesses }\end{array}$} & Agree & $61(64.9)$ & $\begin{array}{l}26 \\
(60.5)\end{array}$ & $35(68.6)$ & \multirow[t]{3}{*}{0.01} & $26(60.5)$ & $35(68.6)$ & \multirow[t]{3}{*}{0.48} \\
\hline & Neutral & $16(17.0)$ & $4(9.3)$ & $12(23.5)$ & & $7(16.3)$ & $9(17.6)$ & \\
\hline & Disagree & $17(18.1)$ & $13(30.2)$ & $4(7.8)$ & & $10(23.3)$ & $7(13.7)$ & \\
\hline
\end{tabular}

Table-2: Comparison between fourth year male and female students regarding the preclinical PBL benefits

\begin{tabular}{|c|c|c|c|c|c|}
\hline Questions & Categories & $\begin{array}{c}\text { Total } \\
\text { Participants } \\
\text { n (\%) }\end{array}$ & $\begin{array}{l}\text { Male } \\
\text { n (\%) }\end{array}$ & $\begin{array}{l}\text { Female } \\
\mathrm{n}(\%)\end{array}$ & $\begin{array}{c}P- \\
\text { value }\end{array}$ \\
\hline \multirow[t]{3}{*}{ PBL helps me to understand basic sciences } & Agree & $26(60.5)$ & $10(50.0)$ & $16(69.6)$ & \multirow[t]{3}{*}{0.19} \\
\hline & Neutral & $9(20.9)$ & $4(20.0)$ & $5(21.7)$ & \\
\hline & Disagree & $8(18.6)$ & $6(30.0)$ & $2(8.7)$ & \\
\hline \multirow{3}{*}{$\begin{array}{l}\text { PBL helps me to increase my basic sciences } \\
\text { knowledge }\end{array}$} & Agree & $31(72.1)$ & $12(6.0)$ & $19(82.6)$ & \multirow[t]{3}{*}{0.18} \\
\hline & Neutral & $4(9.3)$ & $2(10.0)$ & $2(8.7)$ & \\
\hline & Disagree & $8(18.6)$ & $6(30.0)$ & $2(8.7)$ & \\
\hline \multirow[t]{3}{*}{ PBL encourages self-directed learning } & Agree & $24(55.8)$ & $8(40.0)$ & $16(69.6)$ & \multirow[t]{3}{*}{0.14} \\
\hline & Neutral & $10(23.3)$ & $6(30.0)$ & $4(17.4)$ & \\
\hline & Disagree & $9(20.9)$ & $6(30.0)$ & $3(13.0)$ & \\
\hline \multirow{3}{*}{$\begin{array}{l}\text { PBL method helps me improve my decisions making } \\
\text { skills }\end{array}$} & Agree & $29(67.4)$ & $8(40.0)$ & $21(19.3)$ & \multirow[t]{3}{*}{-} \\
\hline & Neutral & $4(9.3)$ & $4(20.0)$ & $0(0.0)$ & \\
\hline & Disagree & $10(23.3)$ & $8(40.0)$ & $2(8.7)$ & \\
\hline \multirow{3}{*}{$\begin{array}{l}\text { PBL method helps me to develop problem-solving } \\
\text { skills }\end{array}$} & Agree & $27(62.8)$ & $12(60.0)$ & $15(65.2)$ & \multirow[t]{3}{*}{0.55} \\
\hline & Neutral & $6(14.0)$ & $2(10.0)$ & $4(17.4)$ & \\
\hline & Disagree & $10(23.3)$ & $6(30.0)$ & $4(17.4)$ & \\
\hline \multirow[t]{3}{*}{ PBL method encourages collaborative learning } & Agree & $20(46.5)$ & $10(50.0)$ & $10(43.5)$ & \multirow[t]{3}{*}{-} \\
\hline & Neutral & $15(34.9)$ & $2(10.0)$ & $13(56.5)$ & \\
\hline & Disagree & $8(18.6)$ & $8(40.0)$ & $0(0.0)$ & \\
\hline \multirow{3}{*}{$\begin{array}{l}\text { PBL method helps me to identify my strengths and } \\
\text { weaknesses }\end{array}$} & Agree & $26(60.5)$ & $12(60.0)$ & $14(60.9)$ & \multirow[t]{3}{*}{-} \\
\hline & Neutral & $7(16.3)$ & $0(0.0)$ & $7(30.4)$ & \\
\hline & Disagree & $10(23.3)$ & $8(40.0)$ & $2(8.7)$ & \\
\hline
\end{tabular}


Table-3: Comparison between fifth year male and female students regarding the preclinical PBL benefits

\begin{tabular}{|c|c|c|c|c|c|}
\hline Questions & Categories & $\begin{array}{c}\text { Total } \\
\text { Participants } \\
\text { n (\%) }\end{array}$ & $\begin{array}{l}\text { Male } \\
\mathrm{n}(\%)\end{array}$ & $\begin{array}{l}\text { Female } \\
\mathrm{n}(\%)\end{array}$ & $\begin{array}{c}P- \\
\text { value }\end{array}$ \\
\hline \multirow[t]{3}{*}{ PBL helps me to understand basic sciences } & Agree & $36(70.6)$ & $17(73.9)$ & $19(67.9)$ & \multirow[t]{3}{*}{0.89} \\
\hline & Neutral & $10(19.6)$ & $4(17.4)$ & $6(21.4)$ & \\
\hline & Disagree & $5(9.8)$ & $2(8.7)$ & $3(10.7)$ & \\
\hline \multirow{3}{*}{$\begin{array}{l}\text { PBL helps me to increase my basic sciences } \\
\text { knowledge }\end{array}$} & Agree & $36(70.6)$ & $17(73.9)$ & $19(67.9)$ & \multirow[t]{3}{*}{0.89} \\
\hline & Neutral & $10(19.6)$ & $4(17.4)$ & $6(21.4)$ & \\
\hline & Disagree & $5(9.8)$ & $2(8.7)$ & $3(10.7)$ & \\
\hline \multirow[t]{3}{*}{ PBL encourages self-directed learning } & Agree & $35(68.6)$ & $16(69.6)$ & $19(67.9)$ & \multirow[t]{3}{*}{0.91} \\
\hline & Neutral & $6(11.8)$ & $3(13.0)$ & $3(10.7)$ & \\
\hline & Disagree & $10(19.6)$ & $4(7.4)$ & $6(21.4)$ & \\
\hline \multirow{3}{*}{$\begin{array}{l}\text { PBL method helps me improve my decisions } \\
\text { making skills }\end{array}$} & Agree & $32(62.7)$ & $14(60.9)$ & $18(64.2)$ & \multirow[t]{3}{*}{0.73} \\
\hline & Neutral & $8(15.7)$ & $3(13.0)$ & $5(17.9)$ & \\
\hline & Disagree & $11(21.6)$ & $6(26.1)$ & $5(17.9)$ & \\
\hline \multirow{3}{*}{$\begin{array}{l}\text { PBL method helps me to develop problem-solving } \\
\text { skills }\end{array}$} & Agree & $36(70.6)$ & 17(73.9) & $19(67,9)$ & \multirow[t]{3}{*}{0.73} \\
\hline & Neutral & $9(17.6)$ & $3(13.0)$ & $6(21.4)$ & \\
\hline & Disagree & $6(11.8)$ & $3(13.0)$ & $3(10.7)$ & \\
\hline \multirow[t]{3}{*}{ PBL method encourages collaborative learning } & Agree & $37(72.5)$ & $15(65.2)$ & $22(78.6)$ & \multirow[t]{3}{*}{0.35} \\
\hline & Neutral & $9(17.6)$ & $6(26.1)$ & $3(10.7)$ & \\
\hline & Disagree & $5(9.8)$ & $2(8.7)$ & $3(10.7)$ & \\
\hline \multirow{3}{*}{$\begin{array}{l}\text { PBL method helps me to identify my strengths } \\
\text { and weaknesses }\end{array}$} & Agree & $35(68.6)$ & $14(60.9)$ & $21(75.0)$ & \multirow[t]{3}{*}{0.31} \\
\hline & Neutral & $9(17.6)$ & $4(17.4)$ & $5(17.9)$ & \\
\hline & Disagree & $7(13.7)$ & $5(21.7)$ & $2(7.1)$ & \\
\hline
\end{tabular}

\section{Figures}


PBL method helps me to identify my strengths and weaknesses

PBL method encourages collaborative learning

PBL method helps me to develop problem-solving skills

PBL method helps me improve my decisions making skills

PBL encourages self-directed learning

PBL helps me to increase my basic sciences knowledge

PBL helps me to understand basic sciences
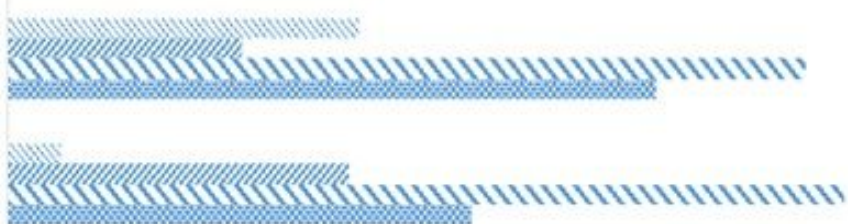

N5th year Male

\% 4 th year Male

$\therefore 5$ th year Female

날 4 th year Female
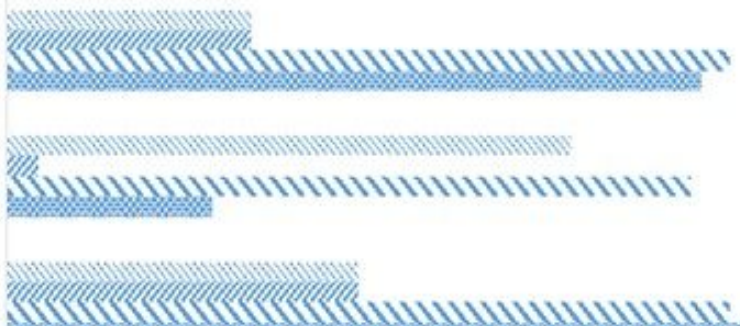

2)
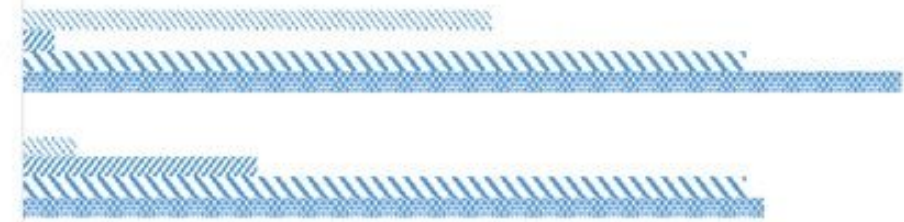

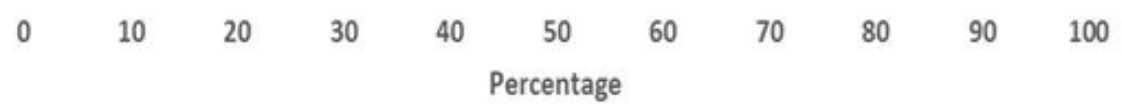

\section{Figure 1}

Comparative analysis between gender and year sub group's perception of the acquired preclinical PBL skill in their clinical phase. 